\title{
FILOZÓFIA SZOCIOLOGIZÁLÓ MEGKÖZELIITÉSBEN: A BÉCSI KÖR TÖRTÉNETE
}

A hagyományos filozófiatörténeti narratíva szerint a logikai empirizmus, amely fénykorát az 1920-as és 30-as években élte, olyan egységes iskola volt, amelyet - többek között - a jelentés és értelmesség verifikacionista felfogása, radikális metafizikaellenesség, a tudományról alkotott és mára meghaladottnak vélt egységes, racionális, kumulatív modell jellemzett. Ezzel a képpel szemben az elmúlt két évtized történetírása nagy részben arról szólt, hogy megpróbálják újraértékelni a logikai empirizmus analitikus filozófiában betöltött szerepét, rámutatva arra, hogy a „bevett nézet” nemcsak hogy leegyszerüsítő, de történetileg sem állja meg a helyét. Tuboly Ádám Tamás Egység és tolerancia címü könyve is egy ilyen vállalkozás, amely egyrészt meggyőzően érvel a bevett nézettel szemben, másrészt pedig túl is mutat ezen a vállalkozáson mint átfogó, tankönyv jellegü munka, amely a jövőben hivatkozási alapként szolgálhat a logikai empirizmussal és a Bécsi Kör filozófiájával foglalkozó magyar nyelvủ szakirodalom számára. Ebből a szempontból fontosnak tartom kiemelni, hogy a könyvet egy több mint hatvanoldalas bibliográfia zárja, felvonultatva a klasszikus szerzőkön túl a legújabb szakirodalmat.

Tuboly szerint már eleve hiba a logikai empirizmusra úgy tekinteni mint egy egységes iskolára, könyvében ezért sokkal inkább mozgalomként hivatkozik rá: ez jobban tükrözi az irányzat heterogén mivoltát, és kiemeli annak társadalmi, mondhatni aktivista jellegét - mindkét elem önmagában ellenvetésként szolgálhat a bevett nézettel szemben (33.). Egyrészt e csoportosulásokban, ellentétben az iskolafilozófiákkal, nem voltak felülről meghatározott és mindenki által egységesen elfogadott tézisek, mindenki a saját eredményeivel járult hozzá a tudományos munkához. Emiatt pedig nem tehetünk , $x$ tézis a Bécsi Kör filozófiáját alapvetően meghatározta" típusú általános kijelentéseket sem. Ezt támasztja alá az is, hogy a tagok közt sok témával kapcsolatban bontakoztak ki éles viták, amelyek közül a jól ismert protokolltétel-vita csak egy a sok közül - Tuboly e vitákat a szembenálló felek álláspontjaival együtt részletesen bemutatja. Másrészt, ami az aktivista jelleget illeti, a bevett nézet szerint a logikai empiristák érzéketlenek voltak a korukban zajló társadalmi változások iránt, amit tudományfilozófiájuk is tükrözött: a pozitivista kép szerint a tudomány érték- és ideológiasemleges, teljes mértékben racionális vállalkozás. Ám, ha a Bécsi Kör által 1929-ben kiadott manifesztumot alaposabban megvizsgáljuk, már abban megjelenik egyfajta tudatos reflexió, amely ,a legújabb filozófiai trendeket azok társadalmi, politikai és gazdasági gyökereihez, mondhatni lehetőség feltételeihez" köti (145.). Emellett pedig 
ne feledkezzünk meg arról a tényről sem, hogy Thomas Kuhn A tudományos forradalmak szerkezete címú múve is a Bécsi Kör által szerkesztett International Encyclopedia of Unified Science sorozatában jelent meg, Rudolf Carnap pedig kifejezetten pozitív véleménnyel volt róla (174.).

Amellett, hogy a szerző sikerrel viszi végig a kitűzött célját, több olyan fejezetet is találhatunk, amely azok számára is újdonság lehet, akik a logikai empirizmus történetét alaposabban ismerik - ezek közül hármat szeretnék itt is kiemelni. Érdekes adalék az 5.5. alfejezet, amelyben a logikai empiristák és a Bauhaus közti viszonyról olvashatunk, az egységes tudomány koncepciójában ugyanis nemcsak a matematikának, logikának és a természettudományoknak volt helye, hanem a müvészeteknek is. Bár a Bauhaust és a Bécsi Kört személyes kapcsolatok is összekötötték, a valódi együttmúködés 1926 után kezdődött, amikor a Bauhaus igazgatói posztjára Hannes Meyer került. Meyer nemcsak a gyakorlatra, hanem az elméletre is nagy hangsúlyt fektetett, és több tudóst is meghívott a Bauhausba, Otto Neurath például két, Carnap pedig öt elöadást is tartott ott (228.). Az együttmüködés hátterét pedig a két szervezet közti eszmei kapcsolat szolgáltatta, amelyet már az is jól szemléltet, ha összevetjük a bauhaus és társadalom címü vers sorait („,mi e népközösség szolgálói vagyunk / amit teszünk, a népet szolgálja”) a Bécsi Kör manifesztumával (,a tudományos világfelfogás az életet szolgálja, az élet pedig befogadja öt") (227.).

Másodszor, a Philipp Frankról szóló fejezet különösen izgalmas: bár Frank neve valószínüleg nem az első, ami eszünkbe jutna, „hanyatlástörténet[e] nem csupán önmagában érdekes, hanem a vele történtek a logikai empirizmusról általában is érdekes tanulságokkal szolgálhatnak" (233.). A bevett nézet ebben a szakaszban is revideálásra kerül: bár hagyományosan úgy tartják, hogy a logikai empirizmus még a 20. század derekán is jelentős szereppel bírt - főleg Amerikában, a Bécsből emigrált filozófusok miatt -, és a mozgalom bukása későbbre, inkább a 60-as évekre tehető W. V. O. Quine kritikájának hatására, Tuboly Frank példáján keresztül mutatja be a feszültségeket és a hanyatlás jeleit, amelyek már az 1940-es évektől megfigyelhetők. A Frank egyéni sorsa és a logikai empirizmus története közti párhuzam kibontása során pedig a szerző bemutatja a franki tudomány- és tudásszociológiát is, amelyben már az 1950-es évektől a tudományon kívüli (politikai, szociológiai, egzisztenciális) tényezők álltak a középpontban (237.).

Harmadszor, a tolerancia elvével foglalkozó 10. fejezet kiemelt fontossággal bír, hiszen Tuboly állítása szerint e tézis „Carnap metafilozófiájának legfontosabb panelje" (394.). A tolerancia elve szük értelemben egy metalogikai tézis, amely szerint teljes szabadságunk van abban, hogy formális rendszerünket milyen szintaktikai szabályok mentén alakítjuk - ez explicit szakítás volt a korszakban domináló monolingvisztikus megközelítéssel, amely szerint egyetlen igaz logika létezik (299-310.). Tágabb értelemben azonban ez egy attitűd is a filozófiai és tudományos vizsgálódás számára, mivel Carnap a teoretikus kérdéseket illető- 
en nem kívánt abszolút igazságokkal elóállni, ezeket inkább aktuális indokai és céljai függvényében alakította (422-426.). A teoretikus tézisek pragmatizmus általi motiválását Tuboly dialektikának nevezi Carnap metafilozófiájában, és a következőképp fogalmazza meg: ,a teoretikus és gyakorlati észhasználat folyamatos kölcsönhatásban van egymással” (418.). A fejezet végén pedig a szerző egy eredeti tézist mutat be, miszerint a tolerancia elve voltaképpen Bertrand Russell és Ludwig Wittgenstein nézeteinek szintézise. Emellett azonban Tuboly kiemeli Carnap korai élettapasztalatait, a Német Ifjúsági Mozgalomban átélt életérzést, személyes intellektuális fejlödését és a Bécsi Körben töltött idejét is.

Amellett tehát, hogy a szerző különböző archívumokból nagy mennyiségủ empirikus adatot használt, túl is lépett a levelezések, kéziratok és személyek közti kapcsolatok feltárásán és ismertetésén, hiszen a logikai empirizmust és annak alakjait a korszak társadalmi beágyazottságával, szociologizáló megközelítéssel is árnyalta. Ezt a megközelítést pedig több helyütt színezik az egyének élettörténeteiből kiragadott releváns epizódok, vagy éppen a köztük zajló viták, amelyek olvasmányossá, „élővé” teszik a könyvet. Emiatt azt gondolom, hogy Tuboly Ádám Tamás Egység és tolerancia címü könyve nemcsak az analitikus filozófia történetével foglalkozó szakemberek, de a tágabban vett müvelt laikusok számára is haszonnal forgatható, érdekes olvasmány.

(Tuboly Ádám Tamás: Egység és tolerancia: A logikai empirizmus tudományos világfelfogása. Budapest: MTA Bölcsészettudományi Kutatóközpont Filozófiai Intézet, 2018.)

Dombrovszki Áron 